\title{
PENGGUNAAN GADGET PADA PEMBELAJARAN DARING TERHADAP MOTIVASI BELAJAR PESERTA DIDIK
}

\author{
Feby Inggriyani ${ }^{1}$, Siti Asiah² \\ ${ }^{1}$ PGSD FKIP Universitas Pasundan, ${ }^{2}$ SDN Bojong 05 Kecamatan Majalaya \\ febyinggriyani@unpas.ac.id, sitiasiah10152326@gmail.com
}

\begin{abstract}
The problem in this research is that online learning causes many obstacles to students' learning motivation. Therefore, teachers must be creative in creating learning innovations through the use of gadgets. The purpose of this study was to determine the effect of using gadgets in learning on the learning motivation of students in class V Elementary School in Lengkong District, Bandung City. The population is 643 students and a sample of 247 students. Sampling was done by using purposive sampling method. Sampling of 247 student respondents and data collection using interviews and questionnaires. The research method uses quantitative descriptive using survey methods. The results showed that there was an effectiveness of using gadgets on students' learning motivation. Students' learning motivation is $4.1 \%$ and the other $95.9 \%$ is influenced by other variables outside of the gadget use variable. The results of the interview show that the weakness of online learning is that not all students understand the learning carried out by the teacher, so that students have difficulty understanding the subject matter, and another factor is the learning environment of students who are less supportive of online learning.
\end{abstract}

Keywords: gadgets, learning motivation, online learning

\begin{abstract}
ABSTRAK
Masalah dalam peneliitian ini adalah pembelajaran daring menimbulkan banyak kendala motivasi belajar peserta didik. Oleh karena itu, guru harus kreatif dalam mencipatkan inovasi pembelajaran melalui penggunaan gadget. Tujuan penelitian ini adalah untuk mengetahui penagruh peggunaan gadget pada pembelajaran terhadap motivasi belajar peserta didik di kelas $V$ Sekolah Dasar yang berada di Kecamatan Lengkong Kota Bandung. Populasinya populasi sebesar 643 orang peserta didik dan sampel sebesar 247 peserta didik. Pengambilan sampel dilakukan dengan menggunakan metode purposive sampling. Pengambilan sampel sebanyak 247 responden peserta didik dan pengumpulan data menggunakan wawancara dan angket. Metode penelitian menggunakan deeskriptif kuantitatif menggunakan metode survei. Hasil penelitian menunjukan bahwa terdapat pengaruh penggunaan gadget terhadap motivasi belajar peserta didik. Motivasi belajar peserta didik sebesar $4,1 \%$ dan $95,9 \%$ lainnya dipengaruhi oleh variabel lain diluar variabel
\end{abstract}


penggunaan gadget. Hasil wawancara menunjukan bahwa kelemahan dari pembelajaran daring yaitu tidak semua peserta didik paham pada pembelajaran yang dilakukan guru, sehingga peserta didik kesulitan dalam memahami materi pelajaran, dan faktor lain yaitu ilingkungan belajar peserta didik yang kurang mendukung dalam pembelajaran daring.

Kata Kunci: gadget, motivasi belajar, pembelajaran daring

\section{A. Pendahuluan}

Penggunaann teknologi adalah menjawab tantangan abad 21 yang penuh kompleksitas dalam bidang pendidikan (Aziz Hussin, 2018; Gamar et al., 2018). Hal ini disebabkan karena penggunaan teknologi dalam pendidikan merupakan sarana yang dapat dipakai sebagai media penyampaian program pembelajaran baik secara searah maupun secara interaktif (Husaini, 2014), dan proses proses pembelajaran tidak lagi dibatasi oleh ruang kelas tertentu (Denker, 2013). Perkembangan pun teknologi telah dan mendorong dan memotivasi pendidik untuk melakukan inovasi dalam menciptakan metode pengajaran di baik di dalam maupun di luar kelas (Almeida \& Simoes, 2019). Dengan demikian, pendidik harus kreatif menggunakan media gadget.

Gadget merupakan elektronik yang dibuat oleh manusia secara khusus sebagai inovasi pada perkembangan teknologi yang semakin canggih dengan berbagai kelebihan yang di milikinya (Husnan, 2013, hlm. 73). Adapun Hudaya (2018, hlm. 89), menyatakan bahwa gadget merupakan sebuah alat yang dibuat berbeda dengan alat elektronik yang lainya karena dilengkapi dengan berbagai keunikan. Hal inilah yang menyebabkan gadget dapat dengan mudah menarik perhatian dan minat peserta didik sehingga banyak anak kecil yang sudah pandai dalam bermain gadget.

Penggunaan teknologi seperti gadget sedang marak digunakan sebagai media pembelajaran daring, apalagi di tengah wabah corona virus disease (Covid-19) di Indonesia menyebabkan Menteri Pendidikan dan Kebudayaan Republik Indonesia mengeluarkan surat edaran Nomor 4 Tahun 2020 tentang Pelaksanaan Kebijakan Pendidikan Dalam Masa Darurat Penyebaran Corona Virus Disease (Covid-19) yang salah satu isinya menyatakan bahwa proses belajar pada seluruh lembaga pendidikan harus di lakukan di rumah 
sebagai upaya pencegahan semakin meluasnya penularan virus corona. Oleh karena itu, guru harus melakukan pembelajaran yang inovatif dengan menggunakan media pembelajaran, salah satunya gadget.

Pendapat Mariskhana (2018:66) menyatakan bahwa penggunaan gadget dapat memberikan dampak yang besar dalam pembentukan cara berpikir dan berperilaku peserta didik, serta dapat menangkap pesan secara audio visual yang dapat terekam dalam pikiran mereka, sehingga dapat berpengaruh kepada kegiatan belajar maupun motivasi belajar peserta didik. Selain itu, Efendi (dalam Mariskhana, 2018, hlm. 63) menyatakan bahwa gadget dapat memberikan dampak positif maupun negatif bagi penggunanya. Faktor-faktor yang memengaruhinya yaitu, 1) menambah pengetahuan peserta didik sehingga mudah dalam mendapatkan informasi dan kaya dengan pengetahuan; 2) melatih kreativitas peserta didik, salah satunya dengan memanfaatkan berbagai fitur layanan seperti game; 3) mengakibatkan peserta didik menjadi cepat puas dengan informasi yang telah didapatnya dari internet sehingga peserta didik menjadi malas untuk menambah pengetahuan dari referensi lain seperti membaca buku; 4) dapat mengganggu konsentrasi belajar, karena dengan fitur canggih yang dimiliki gadget membuat peserta didik menjadi selalu ingin tahu dan tertarik ingin terus menggunakannya sehingga mengganggu pada saat proses pembelajaran.Hal ini sesuai dengan Ibrahim (dalam, Rahmawati, dkk, 2017, hlm. 78) yang menyatakan bahwa penggunaan gadget yang berlebih dapat mengakibatkan gangguan pola tidur serta kerusakan indera penglihatan karena terlalu lama memegang smartphone. Selain itu, kurangnya berkonsentrasi ketika pelajaran, dikarenakan sudah terkait dengan dunia yang tidak nyata (Manumpil, B, dkk, 2015, hlm. 4).

Penggunaan gadget tidak selalu menyebabkan dampak yang negatif bagi penggunanya. Maflikhah (dalam Muhasim, 2017, hlm. 70) menegaskan bahwa penggunaan teknologi digital yang digunakan untuk mencari suatu infornasi sehingga dapat memperoleh suatu hasil yang dibutuhkan dapat memberikan dampak positif bagi penggunanya terlebih bila digunakan oleh peserta didik.

Merujuk dari Theory of Reasoned Action (TRA) dan Fishbein dan Ajzen (dalam Muhasim, 2017, 
hlm. 73) menyatakan bahwa seseorang akan memakai suatu teknologi yang menguntungkan dalam mempermudah pekerjaannya. Oleh karena itu, penggunaan teknologi gadget pada peserta didik apabila dimanfaatkan secara tepat dapat memengaruhi motivasi belajar peserta didik, karena pada dasarnya peserta didik dapat menggunakan gadget untuk mencari informasi dan menambah pengetahuan secara lebih mendalam (Fitriansyah, 2016, hlm. 10). Selain itu, penggunaan media teknologi dapat menumbuhkan motivasi untuk menyelesaikan masalah pembelajaran dengan adanya tantangan, keingintahuan, kebaruan. Motivasi pun sebagai faktor penting untuk keberhasilan belajar. Dengan demikian, pendidik harus meningkatkan motivasi belajar dengan pemanfaatan teknologi pada kegiatan pembelajaran.

Motivasi belajar merupakan hal yang sangat penting untuk dimiliki peserta didik agar tercapainya suatu hasil belajar yang maksimal. Badaruddin (2016:19) menyatakan bahwa motivasi belajar merupakan suatu keinginan yang muncul dari dalam diri peserta didik untuk mencapai suatu tujuan dalam pembelajaran ke arah yang lebih baik, yang dituangkan dalam suatu bentuk perilaku tertentu. Selain itu, pendapat Hamzah (dalam Badaruddin, 2016:18) menyatakan bahwa hakikat motivasi belajar adalah dorongan yang timbul dari dalam dan luar diri peserta didik yang di pengaruhi oleh beberapa faktor untuk merubah tingkah laku dalam mencapai tujuan belajar.

Menanggapi salah satu tantangan di abad 21 yang harus dihadapi saat ini dalam dunia pendidikan, teknologi digital saat ini dapat dipergunakan sebagai media agar mampu menumbuhkan motivasi belajar. Sobon dan Mangundap (2019, hlm. 61) menyatakan bahwa terdapat beberapa cara yang dapat dilakukan dalam menumbuhkan motivasi belajar peserta didik yaitu dapat melalui pembelajaran digital menggunakan gadget yaitu smartphone.

Smartphone dapat membantu menumbuhkan motivasi belajar, jika digunakan sebagai media dalam suatu pembelajaran. Adapunmenurut Irfan, dkk (2019, hlm. 271) dalam penelitiannya menyatakan bahwa penggunaan media sosial melalui gadget handphone menujukan bahwa dengan penggunaan media sosial secara bijak dengan tidak mengakses 
sesuatu yang bersifat negatif, melainkan penggunaannya lebih di maksimalkan ke arah positif seperti sebagai media pembelajaran mampu meningkatkan motivasi ketika belajar.

\section{B. Metode Penelitian}

Jenis penelitian menggunakan penelitian deskriptif kuantitatif menggunakan metode survei. Teknik pengumpulan data mengenai suatu informasi dengan cara mengambil sebuah sampel dari satu populasi, agar memperoleh keterangan yang valid mengenai informasi yang dibutuhkan dalam mengungkap suatu permasalahan melalui pengamatan langsung dan hasil dari angket.

Subjek dalam penelitian ini adalah peserta didik kelas $\mathrm{V}$ di 6 Sekolah Dasar yang berada di Kecamatan Lengkong Kota Bandung dengan jumlah populasi sebesar 643 orang peserta didik dan sampel sebesar 247 peserta didik. Pengambilan sampel peneliti menggunakan Purposive Sampling.

\section{C.Hasil Penelitian dan Pembahasan}

Motivasi belajar memiliki peran yang penting dalam mencapai tujuan pembelajaran. Motivasi belajar tidak hanya berasaldari dalam diri peserta didik tetapi juga dapat berasal dari luar diri seperti pendidik. Dengan memiliki motivasi belajar, maka akan semangat sehingga pembelajaran menjadi lebih terarah dan mencapai tujuan belajar yang telah ditentukan (Emda, 2017:182).

Motivasi belajar peserta didik di Kelurahan Babakan Ciparay Kota Bandung berada pada kategori tinggi, lebih dari setengahnya peserta didik di Kelurahan Babakan Ciparay Kota Bandung memiliki motivasi belajar yang tinggi yaitu sebesar 64\%. Motivasi belajar peserta didik dapat diransang melalui faktor eksternal, seperti penggunaan media pembelajaran melalui gadget (handphone), merujuk kepada hasil angket butir soal nomor 11 yaitu saya merasa malas dalam memahami materi pelajaran yang di berikan pendidik melalui handphone dan sebanyak 52 peserta didik menjawab sangat tidak setuju. Dengan demikian dapat disimpulkan bahwa peserta didik memiliki motivasi belajar ketika memahami materi pelajaran yang diberikan pendidik melalui handphone.

Hal tersebut sesuai dengan penelitian Dauyah dan Yulinar 
(2018, hlm. 207) yang menyatakan bahwa faktor yang penting dalam meningkatkan temotivasi peserta didik ketika belajar yaitu, fasilitas pendukung seperti sarana dan prasarana online. Hal ini akan sangat membantu pembelajaran seperti penggunaan video dan alat peraga alat peraga dapat menjadikan peserta didik menjadi lebih termotivasi sehingga pembelajaran menjadi bermakna.

Berdasarkan hasil analisis data, efektivitas penggunaan gadget (handphone) terhadap motivasi belajar peserta didik kelas $\mathrm{V}$ di Kelurahan Babakan Ciparay Kota Bandung sebesar 4,1\%. Menurut hasil angket yang telah disebarkan pada peserta didik kelas $\mathrm{V}$ di Kelurahan Babakan Ciparay Kota Bandung, dengan persamaan nilai koefisien regresi $X$ sebesar 0,264 menyatakan bahwa setiap penambahan $1 \%$ nilai penggunaan gadget, maka nilai motivasi belajar bertambah sebesar 0,264. Koefisien regresi tersebut bernilai positif, sehingga dapat dikatakan bahwa arah penggunaangadget terhadap motivasi belajar adalah positif.

Berdasarkan hasi dari uji anova dihasilkan nilai $F$ hitung sebesar 10,602 dengan tingkat signifikansi (angka probabilitas) sebesar 0,001. Karena angka signifikan lebih kecil dari nilai $=0,05$, maka artinya terdapat pengaruh yang signifikan antara penggunaan gadget terhadap motivasi belajar peserta didik. Selain itu, nilai signifikansi sebesar 0,01 lebih kecil dari probalilitas 0,05 , sehingga dapat disimpulkan $\mathrm{Ho}$ ditolak dan $\mathrm{Ha}$ diterima, yang berarti bahwa terdapat pengaruh positif dan signifikan dari variabel penggunaan gadget $(X)$ terhadap variabel motivasi belajar $(\mathrm{Y})$ peserta didik kelas V SDN di Kelurahan Babakan Ciparay Kota Bandung. Hal tersebut sesuai dengan hasil penelitian Fitriansyah, (2016, hlm. 10) yang menyatakan bahwa penggunaan teknologi seperti gadget pada peserta didik apabila dimanfaatkan secara tepat dapat memengaruhi motivasi belajar peserta didik, karena pada dasarnya peserta didik dapat menggunakan gadget untuk mencari informasi dan menambah pengetahuan secara lebih mendalam. Adapun manfaat gadget menurut Mahfud dan Aprilya (2018) menjelaskan bahwa dalam pembelajaran adalah memperlancar 
interaksi antara pendidik dengan peserta didik, sehingga terciptanya proses pembelajaran yang efektif dan efisien, materi akan dengan mudah diterima oleh peserta didik dan mampu meningkatkan kemampuan memahami materi pada. Namun, hal tersebut bisa bermanfaat apabila pendidik bisa memanfaatnyannya dengan baik dan menggunakan inovasi pembelajaran yang menarik. Selain itu, Irfan, dkk (2019, hlm. 271) menyatakan bahwa penggunaan gadget secara bijak dengan tidak mengakses sesuatu yang bersifat negatif dapat berpengaruh positif terhadap motivasi peserta didik dalam belajar.

Hasil wawancara kepada 2 orang peserta didik diperoleh informasi bahwa pembelajara yang dilakukan melalui daring menyenangkan sedangkan 5 orang peserta didik yang lainnya merasa pembelajaran lebih menyenangkan ketika belajar secara langsung ketika di sekolah. Ini disebabkan karena peserta didik merasa cepat bosan ketika belajar secara daring. Selain itu, peserta didik kadang merasa kesulitan ketika memahami materi pelajaran. Hal ini disebabkan karena kurang kreatifnya guru dalam menerapkan inovasi pembelajaran. Hal ini sesuai dengan Oktiani (2017:231) yang menyatakan bahwa salahsatu cara untuk meningkatkan motivasi belajar peserta didik dengan guru kreatif dalam menggunakan dan memanfaatan media pembelajaran. Oleh karena itu, unsur-unsur yang mendorong terciptanya motivasi belajar peserta didik adalah 1) tempat belajar dan lingkungan belajar yang kondusif; 2) kondisi fisik peserta didik yang sehat; 3) kecerdasan intelegensi; 4) sarana prasarana pembelajaran; 5) waktu pelaksanaan pembelajaran. Oleh karena itu, perlu adanya upaya yang dilakukan pendidik dalam meningkatkan motivasi belajar dengan cara membangun kepercayaan diri peserta didik, memberikan dorongan dengan mengingatkan kembali tujuan awal yang ingin dicapai dan pendidik menyanjung peserta didik yang tidak mengumpulkan tugas.

\section{E. Kesimpulan \\ Pemanfaatan} teknologi pembelajaran menggunakan gadget dapat memberikan dampak yang positif dalam dunia pendidikan. 
Terdapat pengaruh penggunaan gadget dalam pembelajaran daring terhadap motivasi belajar peserta didik di Kelurahan Babakan Ciparay Kota Bandung yang berada pada kategori rendah dan terdapat pengaruh positif antara penggunaan gadget (hanphone) dengan motivasi belajar peserta didik.

Hasil wawancara dengan peserta didik diperoleh informasi bahwa kelemahan pembelajaran daring yaitu tidak semua peserta didik paham materi pembelajaran serta pembelajaran yang dilakukan guru kurang inovatif dan faktor lain yaitu dari lingkungan belajar peserta didik yang kurang mendukung dalam pembelajaran daring.

\section{DAFTAR PUSTAKA}

Almeida, F., \& Simoes, J. (2019). The Role of Serious Games, Gamification and Industry 4.0 Tools in the Education 4.0 Paradigm. Contemporary Educational Technology, 10(2), 120-136.

Aziz Hussin, A. (2018). Education 4.0 Made Simple: Ideas For Teaching. International Journal of Education and Literacy Studies, 6(3), 92-98.

Badaruddin, Achmad. (2016). Peningkatan motivasi belajar siswa melalui konseling klasikal. Jakarta: CV Abe Kreatifindo.

Dauyah, E. \& Yulinar. (2018). Faktorfaktor yang mempengaruhi motivasi belajarbahasa inggris mahasiswa non-pendidikan bahasa inggris. Jurnal Serambi IImu. 19(2),196-209.

Denker, K. J. (2013). Student Response Systems and Facilitating the Large Lecture Basic Communication Course: Assessing Engagement and Learning. Communication Teacher, 27(1), 50-69.

Emda, Amna. (2017). Kedudukan motivasi belajar siswa dalam pembelajaran.Lantanida Journal. 5(2), 93-196.

Fitriansyah, F. (2016). Pemanfaatan Media Pembelajaran Gadget Untuk Memotibasi Belajar Siswa SD. Cakrawala : Jurnal Humaniora Bina Sarana Informatika.

Gamar, M. M., Al Faruq, M. S., \& Lina, L. (2018). Challenging the Indonesian Primary Education in Industrial Revolution 4.0 Era. 3rd International Conference on Education Management and Administration (CoEMA 2018), 269, 46-48.

Hudaya, A. (2018). Pengaruh gadget terhadap sikap disiplin dan minat belajar peserta didik. Jurnal Of Education. 4(2), 8697.

Husaini, M. (2014). Pemanfaatan Teknologi Informasi dalam Bidang Pendidikan (EEducation). Jurnal Mikrotik, 2(1), 1-5. 
Husnan, Fathul\&Java Creativity. (2013). Buku sakti blogger. Jakarta: PT Elex Media Komputindo.

Irfan, M. Nurasiah, S. \& Rahayu, A, N. (2019). Pengaruh penggunaan media sosial (medsos) secara positif terhadap motivasi belajar siswa sd negeri perumnas kecamatan rappocini kota makasar. Jurnal Publikasi Pendidikan. 9(3), 262272.

Mahfud, M.N., Wulansari Aprilya. (2018). Penggunaan Gadget Untuk Menciptakan Pembelajaran Yang Efektif. Seminar Nasional Pendidikan UMS.

Manumpil, B., Yudi Ismanto, Franly Onibala. (2015). Hubungan penggunaan gadget dengan tingkat prestasi siswa di sma negeri 9 manado. Ejournal Keperawatan (e-Kep). 3(2), 1-6.

Mariskhana, K. (2018). Dampak media sosial (facebook) dan gadgetterhadap motivasi belajar. Jurnal. XVI (1), 62-67.

Muhasim. (2017). Pengaruh teknologi digital, terhadap motivasi belajar peserta didik. Jurnal Studi Keislaman dan IImu Pendidikan. 5(2), 53-77.

Oktiani, I. (2017). Kreativitas guru dalam memotivasi peserta didik. Jurnal kependidikan. 5(2),216232.

Permendikbud. (2020). Peraturan Menteri Pendidikan dan Kebudayaan Republik Indonesia Nomor 4 Tahun 2020 Tentang
Kebijakan Pendidikan Dalam Masa Darurat Penyebaran Corona Virus Disease (Covid19). [Online]. Tersedia: http://pusdiklatkemendikbud.go id/surat- edaran-mendikbudno-4-tahun-2020-tentangpelaksanan-kebijakanpendidikan-dalam-masadarurat-penyebaran-coronavirus-disease-covid- 1-9/ Diakses dari laman web tanggal 18 April 2020.

Rahmawati, H.N., Iqom, M.K.B., dan Hermanto. (2017). Hubungan durasi penggunaan media sosial dengan motivasi belajar remaja. Jurnal Keperawatan. 5(2), 77-81

Sobon, K., Mangundap, J.M. (2019). Pengaruh penggunaan smartphone terhadap hasil belajar siswa sekolah dasar di kecamatan mapanget, kota manado. Jurnal Inovasi Pendidikan Dan Pembelajaran Sekolah Dasar. 3(1), 52-64 